\title{
CONSUMPTION OF MINIMALLY PROCESSED AND ULTRA-PROCESSED FOODS AMONG STUDENTS FROM PUBLIC AND PRIVATE SCHOOLS
}

\section{Consumo de alimentos minimamente processados e ultraprocessados entre escolares das redes pública e privada}

\author{
Camila Silva Ferreira ${ }^{(\mathbb{D})}$, Dyene Aparecida Silva ${ }^{a}$ (D), \\ Cristiana Araújo Gontijo ${ }^{a}$ (D) Ana Elisa Madalena Rinaldia,* (D)
}

\section{ABSTRACT}

Objective: To compare and analyze the consumption of minimally processed and ultra-processed foods among students from public and private schools.

Methods: Study conducted in Uberlândia, MG, with fifth-grade students from three private and six public schools, selected by stratified cluster sampling. We collected data on food consumption using the 24-hour recall. Foods were classified into four groups (G) according to extent and purpose of processing: fresh/minimally processed foods (G1) culinary ingredients (G2), processed foods (G3), and ultra-processed foods (G4). Total energy intake (kcal) of each group, amount of sugar (g), sodium ( $\mathrm{mg}$ ), and fiber (g) were quantified and compared according to administrative affiliation (private or public).

Results: Percentage of total energy intake was: G1 - 52\%; G2 12\%; G3 - 5\%; e G4 - 31\%. Energy intake from G1 (53 vs. 47\%), G2 (12 vs. $9 \%$ ), and G3 (6.0 vs. $0.1 \%$ ), and amount of sodium (3,293 vs. $2,724 \mathrm{mg}$ ) and fiber (23 vs. $18 \mathrm{~g})$ were higher among students from public schools. Energy intake from G4 (36 vs. 28\%) and amount of sugar (20 vs. 14\%) were higher among students from private schools. The consumption of foods from $\mathrm{G} 1$ in the school environment was higher among students from public schools (40 vs. $9 \%$ ).

Conclusions: Foods from $\mathrm{G} 1$ represent the highest percentage of total energy intake, while those from $\mathrm{G} 4$ constitute a third of calories consumed. Processed juice, sandwich cookie, processed cake, and breakfast cereals are more frequent among private school students; snacks and juice powder are more common for students from public schools.

Keywords: Food consumption; Schoolchildren; Industrialized foods.

\section{RESUMO}

Objetivo: Comparar e analisar o consumo de alimentos minimamente processados e ultraprocessados entre escolares das redes pública e privada.

Métodos: Estudo realizado em Uberlândia, MG, com escolares do quinto ano do ensino fundamental em nove escolas (três privadas e seis públicas), selecionados por amostragem estratificada por conglomerado. O consumo alimentar foi analisado utilizando recordatório de 24 horas. Os alimentos foram classificados segundo extensão e propósito do seu processamento em quatro grupos (G): alimentos in natura/minimamente processados (G1), ingredientes culinários (G2), alimentos processados (G3) e ultraprocessados (G4). Os valores energéticos totais (kcal) provenientes de cada grupo, quantidade de açúcar (g), sódio (mg) e fibras (g) foram quantificados e comparados segundo dependência administrativa. Resultados: O consumo de energia foi: G1, 52\%; G2, 12\%; G3, 5\%; e G4, 31\%. Os valores energéticos provenientes de G1 (53 vs. $47 \%)$, G2 (12 vs. $9 \%$ ) e G3 (6,0 vs. 0,1\%), a quantidade de sódio (3.293 vs. $2.724 \mathrm{mg}$ ) e a de fibras (23 vs. $18 \mathrm{~g}$ ) foram superiores em escolares da rede pública. O valor percentual energético do G4 (36 vs. 28\%) e a quantidade de açúcar (20 vs. 14\%) foram superiores em escolares da rede privada. O consumo do G1 na escola foi superior nos escolares da rede pública (40 vs. 9\%).

Conclusões: Alimentos do G1 representam o maior percentual do valor energético total e do $\mathrm{G} 4$, um terço das calorias ingeridas. Suco pronto, biscoito recheado, bolo industrializado, cereais matinais são mais frequentes em escolares da rede privada e salgadinhos e suco em pó nos da rede pública.

Palavras-chave: Consumo alimentar; Escolares; Alimentos industrializados.

*Corresponding author. E-mail: anaelisarinaldi@gmail.com (A.E.M. Rinaldi).

aniversidade Federal de Uberlândia, Uberlândia, MG, Brazil.

Received on September 23, 2017; approved on January 11, 2018; available online on February 19, 2019. 


\section{INTRODUCTION}

The dietary patterns of the world population are changing, mainly due to the higher consumption of ready-to-eat foods, which have high levels of fat and sugar, and lower intake of unprocessed foods, such as fruits, vegetables, tubers, and cereals. ${ }^{1}$ Data analysis of the dietary patterns of Brazilian adults identified that $69.5 \%$ of the total daily calories consumed come from fresh or minimally processed foods, $9.0 \%$ from processed, and $21.5 \%$ from ultra-processed. ${ }^{2}$

These dietary patterns observed in adults are also found in studies with Brazilian children and adolescents, who showed low intake of milk, fruits, and vegetables ${ }^{3}$ and high consumption of foods rich in sugar ${ }^{3,4}$ fat ${ }^{3}$ processed juices, and soft drinks. ${ }^{3,4}$ Results of a study carried out in Pelotas, RS, indicated that $19.7 \%$ of the energy intake in the diet of children younger than 24 months originated from ultra-processed products and this percentage was higher for those older than 24 months (36.1\%). ${ }^{5}$ Among children aged two to ten years assisted at the Basic Health Unit (Unidade Básica de SaúdeUBS), the percentage of energy intake of ultra-processed products was $47.0 \%{ }^{6}$

The National Adolescent Student Health Survey (Pesquisa Nacional de Saúde do Escolar - PeNSE) analyzed the consumption of markers of healthy and non-healthy eating. According to data from the last PeNSE (2015), the regular intake ( $\geq 5$ days/week) of beans was $60.7 \%$; vegetables, $37.7 \%$; fruits, $32.7 \%$; croquettes, $13.7 \%$; candies, $41.6 \%$; soft drinks, $26.7 \%$; and other processed/ultra-processed foods, $31.3 \%$. With respect to food consumption in the school environment, only $38.1 \%$ of public school students reported consuming meals provided by the National School Feeding Program (Programa Nacional de Alimentaçâo Escolar - PNAE). Regarding foods purchased in cafeterias or brought from home and consumed during school hours, the prevalence of soft drinks, candies, and processed snacks among public school students was 58.5, 49.7, and $63.7 \%$, and for private school students, it was $70.6,62.3$, and $60.0 \%$, respectively. ${ }^{7}$

Analysis of food intake among students from public and private schools and the prevalence of consumption in intraand extra-school environments allow us to identify differences and similarities in these environments, as well as substantiate the elaboration of intervention strategies. Additionally, the dietary intake research based on the degree and extent of processing is consistent with the verification conducted with the Brazilian population and with the classification proposed by the Dietary Guidelines for the Brazilian Population. ${ }^{8}$ Thus, the objectives of this study were to compare and analyze the consumption of minimally processed, processed, and ultra-processed foods among students from public and private schools.

\section{METHOD}

Cross-sectional study performed with fifth-grade students from private and municipal public schools in Uberlândia, MG, from March to August 2013. In that year, the city had 37 municipal schools with 4,192 students regularly enrolled and 73 private schools with 1,186 students. These schools were distributed in five geographic city areas (downtown, west, east, north, and south).

Students were chosen by stratified cluster sampling in two stages. The first stage consisted of selecting schools by stratified sampling, considering the city area and administrative affiliation (public and private) in proportion to the number of students; the second selected fifth-grade classes from each school. Sample size calculation considered 30 students per class upon prior consultation with the schools. The final estimated sample was 270 fifth-grade students distributed in nine schools (six public and three private) at a ratio of $3: 1$, respectively, with a maximum error of $6 \%$.

The total number of students enrolled in the selected classes was 272 (205 from public and 67 from private schools). However, due to some students refusing to participate, guardians not signing the informed consent form, and implausible total energy intake $(\leq 400$, and $\geq 7000 \mathrm{kcal}),{ }^{9}$ the final sample comprised 206 students, 151 from public and 55 from private schools (response rate $=76 \%$ ).

We collected data on food consumption using a 24-hour recall of a typical day of the week. Fifth-grade students were chosen precisely for their age group, as only around 10 to 12 years, the individual can give more reliable answers about food consumption. ${ }^{10}$

A pilot study previously tested the use of the instrument to estimate the time of application, collection logistics, and possible doubts. The 24-hour recall followed the five steps recommended by the United States Department of Agriculture, in order to improve quality and reliability of foods reported. ${ }^{11}$

We used photographic records ${ }^{12}$ and described quantities in a table with household measures ${ }^{13}$ to assist students in determining the amount of food consumed. The software Diet Pro $5 \mathrm{i}$ estimated the total energy intake $(\mathrm{kcal})$ and amount of sugar (kcal), sodium (mg), and dietary fibers (g), using the Brazilian Food Composition Table ${ }^{14}$ as a reference, complemented by the United States Department of Agriculture Food Composition Databases. ${ }^{15}$ For meals and/or preparations which were not in the selected tables, we used the standardization of recipes proposed by Pinheiro ${ }^{13}$ and information on nutrition labels for ultra-processed foods.

Food classification based on the extent and purpose of processing followed the 2010 proposal by Monteiro and 
collaborators ${ }^{16}$ updated in $2012 .{ }^{17}$ All foods reported in the 24-hour recall were categorized into the following groups:

- G1) Fresh or minimally processed foods;

- G2) oils, fats, salt, and sugar, or culinary ingredients;

- G3) processed foods;

- G4) ultra-processed foods.

We separated the ingredients of all culinary preparations (e.g., pasta with tomato sauce, meatball, rice and beans, polenta with minced meat, among others) to classify them in their respective food groups. All recipes were based on a table of preparation with household measures ${ }^{13}$ to adopt a standard and due to students not knowing the ingredients of the meals.

The analyses of food consumption focused on the description of total energy intake, percentage of total energy intake of each group (G1, G2, G3, and G4) based on the extent and purpose of food processing, percentage of total energy intake of sugar, and total amount of sodium ( $\mathrm{mg}$ ) and dietary fibers (g) consumed. We also analyzed the percentage of total energy intake in the school environment separately. Public school students answered questions on the consumption of meals provided by the Municipal School Feeding Program. All analyses considered the group of children from the sample and administrative affiliation of the school.

Categorical variables were expressed in relative frequencies. The Shapiro-Wilk test evaluated the normality of continuous variables. Both were described as median and 1 st (1stQ) and 3rd quartiles (3rdQ). We used the Mann-Whitney test to analyze continuous variables according to administrative affiliation, and the chi-square test for categorical variables. All observations were corrected by the design effect (clustering) using the weighting factor (sampling weight). We adopted a significance level of $5 \%$. The software Epi-Info ${ }^{\oplus}$ version 3.5.2 analyzed the data. The Research Ethics Committee of Universidade Federal de Uberlândia approved this study - report no. 461540/Certificate of Presentation for Ethical Consideration (Certificado de Apresentação para Apreciação Ética-CAAE): 06257813.70000.5152.

\section{RESULTS}

This study comprised 206 students: 151 (78\%) from public and $55(22 \%)$ from private schools. Most were females (53\%), with no difference regarding administrative affiliation $(\mathrm{p}=0.69)$. The median 1stQ-3rdQ age of public school students was superior to that of private school students $[10.6(1 \mathrm{stQ}=10.2$; $3 \mathrm{rdQ}=11.2)$ vs. 10.2 years $(1 \mathrm{st} \mathrm{Q}=10.0 ; 3 \mathrm{rdQ}=10.5)](\mathrm{p}<0.001)$.

Considering the value and percentage of energy intake according to food groups, G1 (52\%) is predominant among all students, followed by G4 (31\%), G2 (12\%), and G3 (5\%). With respect to administrative affiliation, the total energy intake by students from public schools was superior to those from private schools. The value and percentage of energy intake of foods from G1, G2, and G3 were higher for public school students, while for G4, the numbers were superior among students from private schools. Sugar intake was greater among private school students, and sodium and dietary fibers were higher in those from public school (Table 1).

Table 2 lists the foods reported by students. Regarding foods from G1, the consumption of rice and meat was predominant for all students. Intake of milk, vegetables, fruits, flour, and eggs was greater among private school students, while consumption of beans, pasta, and coffee was higher among the ones from public schools. Consumption of culinary ingredients (G2) differed only for butter, more consumed by public school students. The profile of foods from G4 was distinct between students from public and private schools. Private school students consumed more products such as processed juice, sandwich cookie, milk-based sugary drinks, breakfast cereals, processed cakes, and processed meat products (Table 2).

The percentage of students who reported consuming some type of food exclusively within the school environment was $74 \%$. This consumption is more frequent in private schools than in public ones (93 vs. $69 \%$; $\mathrm{p}<0.001$ ). Only $40 \%$ of public school students declared consuming preparations provided by the Municipal School Feeding Program. The median energy intake, in kcal, in the school environment was higher among students from private schools compared to public ones [284 (1stQ=198; 3rdQ=361) vs. $170(1 \mathrm{stQ}=0 ; 3 \mathrm{rdQ}=370)$; $\mathrm{p}<0.001$, representing 15 to $9 \%$ of the total energetic intake, respectively (data not shown in tables).

After analyzing food consumption within the school environment in more detail, we found that the percentage of energy intake of foods from G1 was higher among students from public schools ( 23 vs. $7 \%$; $p<0.001$ ). In $\mathrm{G} 1$, only the intake of fruit and fresh fruit juice within the school environment was superior among private school students (Table 3 ). The percentage of energy intake of foods from G4 was predominant in students from private schools ( 35 vs. $16 \% ; \mathrm{p}<0.001$ ) (data not shown in tables).

\section{DISCUSSION}

The classification of foods and food products adopted in this study favors the analysis of food sources and way of processing. Analyzes focused only on nutrients are insufficient to demonstrate the relationship between the negative effects of processed and ultra-processed products. ${ }^{18}$ Moreover, this new approach is 
more comprehensive and enables targeting intervention strategies undertaken by health professionals.

The main results found in the present study were:

- Foods from G1 represent the highest percentage of daily energy intake among students from both private and public schools, followed by foods from G4, higher among private school students.

- The profile of fresh/minimally processed and ultra-processed foods consumed by students differ according to the type of school administration.

- Preparations provided by the Municipal School Feeding Program are a good alternative to potentially reduce the consumption of ultra-processed foods in the school environment and could contribute to increasing the percentage of daily energy intake of foods from G1.

In this study, the foods from G1 most consumed by students (rice, meat, and beans) are similar to those consumed by the Brazilian population. ${ }^{16}$ We identified a higher fiber intake among public school students, possibly due to the greater percentage of energy from the consumption of beans. A study suggests that non-habitual consumption of beans is a risk factor for insufficient dietary fiber intake. ${ }^{19}$

The purchase and consumption of some foods from G1, such as milk, fruits, and vegetables, tend to increase with a higher income. ${ }^{16}$ In the present study, we also observed a greater frequency of milk, fruits, and vegetables among private school students. However, this comparison should be made with caution since we did not analyze income. ${ }^{20}$

As for foods from G3, bread was one of the products with a higher incidence of consumption in this and other studies. ${ }^{16,21}$ Processed bread was more frequent among students from public schools and ultra-processed ones among those from private schools. Foods from G4 represented more than one-third of the energy consumed, a result similar to the pattern described for the Brazilian population. ${ }^{2,16}$ Although more than $30 \%$ of the total energy intake by students from private and public schools corresponded to foods from G4, there is a difference in the profile of foods consumed. Candies were the most consumed among students, with no significant difference between public and private schools.

In the study by Monteiro, ${ }^{16}$ all food products, except cookies and processed meat, were more consumed as income increased. In the present study, the products most often mentioned by public school students were juice powder, and processed snacks and popcorn. In private schools, there was a predominance of cheese, processed juice, sandwich cookie, croquettes, salty pastries, and French fries, breakfast cereal and granola bar, milk-based sugary drinks, processed meat products, and processed muffin. Despite our results being similar to those identified by Monteiro et al., ${ }^{16}$ we emphasize that it is impossible to state that income can explain the difference in the profile of foods consumed by students from public and private schools.

Table 1 Total energy intake and percentage of energy intake of each food group, percentage of energy intake of sugar, and amount of sodium and fiber consumed by students from public and private schools. Uberlândia, MG, $2013(n=206)$.

\begin{tabular}{|c|c|c|c|c|}
\hline & Total & Public & Private & p-value* \\
\hline TEl (kcal) & $1943(1555 ; 2439)$ & $2010(1555 ; 2476)$ & $1802(1524 ; 2031)$ & 0.01 \\
\hline Group 1 (kcal) & $934(748 ; 1227)$ & $989(755 ; 1274)$ & $838(696 ; 985)$ & $<0.001$ \\
\hline Group 1 (\%) & $52(44 ; 60)$ & $53(45 ; 62)$ & $47(40 ; 54)$ & $<0.001$ \\
\hline Group 2 (kcal) & $198(146 ; 275)$ & $207(162 ; 288)$ & $144(110 ; 235)$ & $<0.001$ \\
\hline Group 2 (\%) & $12(8 ; 14)$ & $12(9 ; 14)$ & $9(6 ; 13)$ & $<0.001$ \\
\hline Group 3 (kcal) & $84(0 ; 153)$ & $147(1 ; 153)$ & $2(0 ; 135)$ & $<0.001$ \\
\hline Group 3 (\%) & $5(0 ; 9)$ & $6(0 ; 10)$ & $0.1(0 ; 6)$ & $<0.001$ \\
\hline Group 4 (kcal) & $569(316 ; 860)$ & $544(293 ; 817)$ & $656(455 ; 1010)$ & $<0.001$ \\
\hline Group $4(\%)$ & $31(19 ; 42)$ & $28(18 ; 40)$ & $36(28 ; 46)$ & $<0.001$ \\
\hline Sugar (kcal) & $290(153 ; 532)$ & $285(136 ; 492)$ & $333(206 ; 621)$ & $<0.001$ \\
\hline Sugar (\%) & $15(9 ; 24)$ & $14(8 ; 22)$ & $20(13 ; 27)$ & $<0.001$ \\
\hline Sodium (mg) & $3107(2537 ; 4084)$ & $3293(2632 ; 4234)$ & $2724(2254 ; 3392)$ & $<0.001$ \\
\hline Fiber (g) & $21(16 ; 29)$ & $23(17 ; 31)$ & $18(12 ; 22)$ & $<0.001$ \\
\hline
\end{tabular}

Values expressed as median (1st quartile; 3rd quartile); *for this analysis, we used the Mann-Whitney test; Group 1: fresh or minimally processed foods; Group 2: culinary ingredients; Group 3: processed foods; Group 4: ultra-processed foods; TEl: total energy intake; kcal: kilocalories; mg: milligrams; g: grams. 
Table 2 Percentage of food consumed by students according to food groups and type of school. Uberlândia, MG, $2013(n=206)$.

\begin{tabular}{|c|c|c|c|}
\hline Food & $\begin{array}{c}\text { Public } \\
\%\end{array}$ & $\begin{array}{c}\text { Private } \\
\%\end{array}$ & p-value \\
\hline \multicolumn{4}{|l|}{ Fresh or minimally processed foods (G1) } \\
\hline Rice & 96 & 94 & 0.48 \\
\hline Meat & 95 & 93 & 0.25 \\
\hline Beans & 89 & 69 & $<0.001$ \\
\hline Vegetables & 68 & 85 & $<0.001$ \\
\hline Milk & 62 & 73 & 0.02 \\
\hline Fruits & 56 & 76 & $<0.001$ \\
\hline Pasta & 37 & 11 & $<0.001$ \\
\hline Coffee & 31 & 9 & $<0.001$ \\
\hline Roots and tubers & 24 & 18 & 0.19 \\
\hline Eggs & 23 & 34 & 0.01 \\
\hline Flour & 18 & 33 & $<0.001$ \\
\hline Other* & 7 & 9 & 0.51 \\
\hline \multicolumn{4}{|l|}{ Culinary ingredients (G2) } \\
\hline Vegetable oil & 99 & 100 & 0.37 \\
\hline Table salt & 99 & 100 & 0.37 \\
\hline Sugar & 53 & 60 & 0.17 \\
\hline Butter & 16 & 5 & $<0.001$ \\
\hline Olive oil & 3 & 5 & 0.26 \\
\hline \multicolumn{4}{|l|}{ Processed foods (G3) } \\
\hline Bread & 65 & 51 & $<0.001$ \\
\hline Canned and preserved foods & 36 & 34 & 0.80 \\
\hline Cheese & 26 & 36 & 0.02 \\
\hline \multicolumn{4}{|l|}{ Ultra-processed foods (G4) } \\
\hline Candies & 59 & 51 & 0.11 \\
\hline Soft drinks & 47 & 40 & 0.17 \\
\hline Juice powder & 45 & 13 & $<0.001$ \\
\hline Chocolate powder & 42 & 51 & 0.07 \\
\hline Margarine & 40 & 44 & 0.52 \\
\hline Cold cuts & 28 & 34 & 0.20 \\
\hline Processed juice & 20 & 36 & $<0.001$ \\
\hline Cakes and cookies & 19 & 16 & 0.48 \\
\hline Processed snacks and popcorn & 17 & 7 & 0.01 \\
\hline Sandwich cookie & 16 & 27 & $<0.001$ \\
\hline Cracker & 11 & 16 & 0.13 \\
\hline Bread & 9 & 22 & $<0.001$ \\
\hline Milk-based sugary drinks & 9 & 18 & $<0.001$ \\
\hline Breakfast cereal and granola bar & 5 & 14 & $<0.001$ \\
\hline Condensed milk & 5 & 5 & 0.71 \\
\hline Cream & 4 & 13 & $<0.001$ \\
\hline Croquettes, salty pastries, and French fries & 3 & 25 & $<0.001$ \\
\hline Processed muffin & 3 & 13 & $<0.001$ \\
\hline Processed meat products** & 3 & 13 & $<0.001$ \\
\hline Mayonnaise & 2 & 11 & $<0.001$ \\
\hline Other*** & 7 & 7 & 0.80 \\
\hline
\end{tabular}

"Chi-square test; *other cereals (corn and oat), oilseeds, honey, and teas; **bacon, hamburger, and nuggets; ***ketchup, sweetener, and instant noodles. 
Table 3 Percentage of food consumed by students in the school environment according to food groups and type of school. Uberlândia, MG, 2013 ( $n=206)$.

\begin{tabular}{|c|c|c|c|}
\hline Item consumed & $\begin{array}{l}\text { Public } \\
\%\end{array}$ & $\begin{array}{l}\text { Private } \\
\%\end{array}$ & p-value $\#$ \\
\hline $\begin{array}{l}\text { Fresh or minimally } \\
\text { processed foods (G1) }\end{array}$ & 39 & 9 & $<0.001$ \\
\hline Meat* & 30 & 0 & $<0.001$ \\
\hline Rice* & 24 & 0 & $<0.001$ \\
\hline Beans* & 20 & 0 & $<0.001$ \\
\hline Pasta* & 11 & 0 & $<0.001$ \\
\hline Vegetables* & 9 & 0 & $<0.001$ \\
\hline Eggs* & 3 & 0 & 0.07 \\
\hline Milk & 2 & 0 & 0.12 \\
\hline Fruit and fresh fruit juice & 1 & 11 & $<0.001$ \\
\hline Culinary ingredients (G2) & 37 & 4 & $<0.001$ \\
\hline Vegetable oil* & 36 & 0 & $<0.001$ \\
\hline Table salt* & 36 & 0 & $<0.001$ \\
\hline Sugar & 6 & 4 & 0.32 \\
\hline Processed foods (G3) & 17 & 9 & $<0.001$ \\
\hline Tomato paste* & 10 & 0 & $<0.001$ \\
\hline Bread & 6 & 7 & 0.22 \\
\hline Ultra-processed foods (G4) & 45 & 89 & 0.36 \\
\hline Candies & 20 & 7 & $<0.001$ \\
\hline Processed juice & 10 & 24 & $<0.001$ \\
\hline Processed snacks & 5 & 5 & 0.94 \\
\hline $\begin{array}{l}\text { Croquettes and salty } \\
\text { pastries }\end{array}$ & 4 & 24 & $<0.001$ \\
\hline Sandwich cookie & 4 & 18 & $<0.001$ \\
\hline Cakes and cookies & 3 & 7 & 0.05 \\
\hline Soft drink & 2 & 14 & $<0.001$ \\
\hline Chocolate powder* & 2 & 0 & 0.12 \\
\hline Processed muffin & 1 & 11 & $<0.001$ \\
\hline Milk-based sugary drinks & 1 & 13 & $<0.001$ \\
\hline Bread & 0 & 2 & $<0.001$ \\
\hline Margarine & 0 & 2 & $<0.001$ \\
\hline Other** & 2 & 9 & $<0.001$ \\
\hline
\end{tabular}

"Chi-square test; *foods provided by the Municipal School Feeding Program; ** cracker, granola bar, mortadella, and requeijão (Brazilian cream-cheese)
Ultra-processed products frequently consumed within the school environment by students from private schools in different Brazilian regions were processed juice, croquettes and salty pastries, sandwich cookie, and soft drink. ${ }^{22-24}$ Although there is no recommendation on the adequate percentage of intake for these products, these values are clearly high, particularly when considering the excess sugar and sodium and low content of dietary fiber found in the foods consumed by students. The percentage of energy contribution in each food group can vary according to income, showing an inverse relationship with the intake of foods from G1 and G2 and a direct relationship from G3 and G4. ${ }^{25}$ However, a research conducted in Brazil shows that this contribution has a direct relationship with the group with fresh/minimally processed, processed, and ultra-processed foods, and an inverse relationship with culinary ingredients. ${ }^{19}$

Most ultra-processed products are semi-perishable and require no prior preparation for consumption, being also defined as "convenience foods" or "fast foods". ${ }^{26}$ They are designed to be portable, practical, and accessible, inducing eating patterns such as skipping main meals, eating while doing other activities - e.g., watching television, driving a car, or working -, and eating alone, ${ }^{26}$ factors that mainly relate to overweight. ${ }^{27}$ Another relevant reason to stimulate the decrease in their consumption is the weakening of traditional food cultures and loss of culinary diversity. ${ }^{27}$

We identified that $40 \%$ of students consume meals provided by public schools. Sturion et al. ${ }^{28}$ revealed that $46 \%$ of students consumed the meal served by the school. These results are alarming since students prefer products of low nutritional quality. ${ }^{28} \mathrm{~A}$ study by Cruz et al. ${ }^{29}$ showed that $84.4 \%$ of students consumed school meals and $28 \%$ bought ultra-processed foods at cafeterias near the school. The availability of ultra-processed foods in the surroundings of public schools was superior to that of minimally processed products, favoring the consumption of ultra-processed foods in the school environment. ${ }^{30}$

We underline the analysis of food consumption in this age group aligned with the proposal by Monteiro ${ }^{16}$ and later with the Dietary Guidelines for the Brazilian Population ${ }^{8}$ as the main positive point of this study. This classification allowed us to consider, at the same time, food consumption having food and food combinations as the main object and, indirectly, the nutrients found in these foods. Additionally, this classification enables nutritional education programs to focus on foods and food preparations, while respecting the culture, local eating habits, and even rescuing the cuisine.

The limitations to be highlighted relate mainly to the application of a 24-hour recall for each student, the adoption of 
recipe standardization, and the sample number being lower than the one proposed by the sample size calculation, especially in public schools $(82 \%$ in private and $73 \%$ in public schools). Despite the sample having 206 recalls, which contributed to reducing inter-individual variability, the application of more than one recall could decrease inter-individual variability even more. Concerning recipe standardization, we needed to adopt a model for the preparations reported by the students since they did not know the ingredients of all meals consumed. Standardization of amounts of oil and salt added to preparations can impact the results found, particularly because oil affects the energy intake. As we use default values, it is possible we underestimated oil and especially salt consumption.

The lack of maternal schooling and income data to verify the direct effect of socioeconomic factors on food consumption was also considered a limitation. These data were not collected since, in the pilot study, we found that students did not know this information, and the administration of the schools did not allow us to access it in the school records. Thus, we used the type of administrative affiliation as a proxy of these factors. We believe that this study represented different incomes due to the clustering of the sample by geographical city areas.

A final limitation identified was the time interval between data collection (2013) and its publication. Despite the fouryear interval, we did not find changes in educational policies or school interventions that could alter the food intake among students in this period. We know that schools work the subject of school feeding in isolation, mainly on themed days (such as fruit day, and World Food Day). Data from PeNSE (2009, 2012, 2015) and the Household Budget Survey (HBS) (20022003 and 2008-2009) are still used in recent publications, even with time intervals exceeding five years.

Public school students show a higher percentage of energy intake of foods from G1, including in the school environment, possibly as a result of the preparations provided by the school feeding program. On the other hand, the percentage of foods from G4 was higher among students from private schools, both in the intra- and extra-school environment. Although the percentage of energy intake of foods from G4 among public school students was lower than for those from private schools, the consumption of these foods also represents a significant percentage of the daily energy intake for this population, with differences concentrated in the type of food consumed. Some ultra-processed foods consumed by students from public and private schools differed. Students from private schools consumed more processed juice, sandwich cookie, processed cake, breakfast cereals, and milk-based sugary drinks, while for public school students, the intake of snacks and juice powder was more frequent. In this scenario, developing strategies for nutrition education targeted at students from both private and public schools and their families is essential.

\section{Funding}

This study did not receive funding.

\section{Conflict of interests}

The authors declare no conflict of interests.

\section{REFERENCES}

1. Popkin BM. The nutrition transition and obesity in the developing world. J Nutr. 2001;31:871S-3S.

2. Louzada ML, Martins AP, Canella DS, Baraldi LG, Levy RB, Claro RM, et al. Ultra-processed foods and the nutritional dietary profile in Brazil. Rev Saude Publica. 2015;49:38.

3. Conceição SI, Santos CJ, Silva AA, Silva JS, Oliveira TC. Food consumption of schoolchildren from private and public schools of São Luis, Maranhão, Brazil. Rev Nutr. 2010;23:993-1004.

4. Carmo MB, Toral N, Silva MV, Slater B. Consumption of sweets, soft drinks and sugar-added beverages among adolescents from public schools in Piracicaba, Sao Paulo. Rev Bras Epidemiol. 2006;9:121-30.

5. Karnopp EV, Vaz JS, Schafer AA, Muniz LC, Souza RL, Santos I, et al. Food consumption of children younger than 6 years according to the degree of food processing. J Pediatr (Rio J). 2017;93:70-8.
6. Sparrenberger K, Friedrich RR, Schiffner MD, Schuch I, Wagner MB. Ultra-processed food consumption in children from a Basic Health Unit. J Pediatr (Rio J). 2015;91:535-42.

7. Brasil. Ministério do Planejamento, Orçamento e Gestão. Instituto Brasileiro de Geografia e Estatística. Pesquisa Nacional de Saúde do Escolar - 2015. Rio de Janeiro: IBGE; 2016.

8. Brasil. Ministério da Saúde. Secretaria de Atenção à Saúde. Departamento de Atenção Básica. Guia Alimentar para a População Brasileira. Brasília: Ministério da Saúde; 2014.

9. Cutler GJ, Flood A, Hannan P, Neumark-Sztainer D. Multiple sociodemographic and socioenvironmental characteristics are correlated with major patterns of dietary intake in adolescents. J Am Diet Assoc. 2011;111:230-40.

10. Cavalcante AA, Priore SE, Franceschini SC. Food consumption studies: general methodological aspects and its use in the evaluation of children and adolescents aged. Rev Bras Saude Matern Infant. 2004;4:229-40. 
11. Moshfegh AJ, Rhodes DG, Baer DJ, Murayi T, Clemens JC, Rumpler WV, et al. The US Department of Agriculture Automated Multiple-Pass Method reduces bias in the collection of energy intakes. Am J Clin Nutr. 2008;88:324-32.

12. Monteiro JP, Pfrimer K, Tremeschin MH, Molina MC, Chiarello $\mathrm{P}$, coordenadoras. Nutrição e metabolismo. Consumo alimentar. Visualizando porções. Rio de Janeiro: Guanabara Koogan; 2010.

13. Pinheiro AB, Lacerda EM, Benzecry EH, Gomes MC, Costa VM, editores. Tabela para Avaliação de Consumo Alimentar em Medidas Caseiras. $5^{\text {a }}$ ed. São Paulo: Editora Atheneu; 2008.

14. Núcleo de Estudos e Pesquisas em Alimentação. Tabela Brasileira de Composição de Alimentos - TACO. $4^{a}$ ed. Campinas: NEPA, UNICAMP; 2011.

15. US Department of Agriculture. Agricultural Research Service. USDA National Nutrient Database for Standard Reference. Washington (DC): US Department of Agriculture; 2001.

16. Monteiro CA, Levy RB, Claro RM, Castro IR, Cannon G. A new classification of foods based on the extent and purpose of their processing. Cad Saude Publica. 2010;26:2039-49.

17. Monteiro CA, Cannon G, Levy RB, Claro RM, Moubarac JC. The Food System. Ultra-processing. The big issue for disease, good health, well-being. World Nutr. 2012;3:527-69.

18. Canella DS, Levy RB, Martins AP, Claro RM, Moubarac JC, Baraldi LG, et al. Ultra-processed food products and obesity in brazilian households (2008-2009). PLoS One. 2014:9:e92752.

19. Vitolo MR, Campagnolo PD, Gama CM. Factors associated with risk of low dietary fiber intake in adolescents. J Pediatr. 2007;83:47-52.

20. Claro RM, Maia EG, Costa BV, Diniz DP. Food prices in Brazil: prefer cooking to ultra-processed foods. Cad Saude Publica. 2016;32:e00104715.

21. Moubarac JC, Martins AP, Claro RM, Levy RB, Cannon G, Monteiro CA. Consumption of ultra-processed foods and likely impact on human health. Evidence from Canada. Public Health Nutr. 2013;16:2240-8.

22. Tavares LF, Fonseca SC, Garcia Rosa ML, Yokoo EM. Relationship between ultra-processed foods and metabolic syndrome in adolescents from a Brazilian Family Doctor Program. Public Health Nutr. 2012;15:82-7.

23. Medeiros CC, Cardoso MA, Pereira RA, Alves GT, França IS, Coura AS, et al. Nutritional status and habits of life in school children. Rev Bras Crescimento Desenvolv Hum. 2011;21:789-97.

24. Novaes JF, Priore SE, Franceschini SC. Estado nutricional e hábitos alimentares de adolescentes de escola privada. Biosci J. 2004;20:97-105.

25. Monteiro CA, Levy RB, Claro RM, Castro IR, Cannon G. Increasing consumption of ultra-processed foods and likely impact on human health: evidence from Brazil. Public Health Nutr. 2010;14:5-13.

26. Monteiro CA. Nutrition and health. The issue is not food, nor nutrients, so much as processing. Public Health Nutr. 2009;12:729-31.

27. Monteiro CA. All the harmful effects of ultra-processed foods are not captured by nutrient profiling. Public Health Nutr. 2009;12:1968.

28. Sturion GL, Silva MV, Ometto AM, Furtuoso CO, Pipitone $M A$. Conditioning factors of students participation in the Brazilian school meal program. Rev Nutr. 2005;18:167-81.

29. Cruz AC, Paiva SM, Xavier SA, Quintão DF. Comparative study of the quality of the snack and physical activity of students in public and private schools in Ipatinga (MG). Rev Cient Faminas. 2014;9:71-90.

30. Leite FH, Oliveira MA, Cremm EC, Abreu DS, Maron LR, Martins PA. Availability of processed foods in the perimeter of public schools in urban areas. J Pediatr (Rio J). 2012;88:328-34. 